\title{
Gondolatok a 2020. év küszöbén
}

Eredmények - feladatok

\author{
Nagy Levente - Tóth Balázs - Ádám József
}

DOI: https://doi.org/10.30921/GK.72.2020.1.1

Absztrakt: Az irás az Agrárminisztérium Földügyi és Térinformatikai Föosztálya, a Miniszterelnökség Ingatlannyilvántartási és Térképészeti Főosztálya valamint a Magyar Földmérési, Térképészeti és Távérzékelési Társaság (MFTTT) vezetôinek évértékelô és az új év tekintetében feladatismertetô összefoglalója. A földmérés és térképészet ágazati irányítását érintố mélyreható közigazgatási átalakítás után a megváltozott és újonnan létrejött szervezetek müködési rendjének kialakítása mellett az ágazat müködését meghatározó jogszabályok módosításának elôkészítése volt az egyik legfontosabb feladat 2019-ben. Az új esztendóben elvégzendô feladatok közül a föhatóságok életében kiemelt jelentôséggel bír az osztatlan közös tulajdon megszüntetésére irányuló program folytatása és az e-ingatlan-nyilvántartási projekt beinditása. Az MFTTT célja változatlanul a magyar földmérés és térképészet szakmai-társadalmi eseményeinek szervezése, koordinálása, az elért eredmények közreadása hazai és nemzetközi szinten egyaránt, valamint az ehhez szükséges szervezeti keretek fenntartása.

Abstract: This paper is a summary of the annual evaluations and forthcoming tasks by the heads of the Department of Land Administration and Geoinformation in the Ministry of Agriculture, the Department of Land Registration and Mapping in the Office of the Prime Minister, and the Hungarian Society of Surveying, Mapping and Remote Sensing. After the radical administrative changes in the sectorial management of surveying and mapping in 2019, one of the most important tasks - in addition to forming the operation of the new organizations - was to prepare the modification of laws regulating the operation of this sector. The continuation of the programme of terminating the undivided common properties and the implementation of the e-real estate project are tasks that are of primary importance in the life of the supreme authorities. The objectives of the Hungarian Society of Surveying, Mapping and Remote Sensing did not change: to organize and coordinate the professional-social events of Hungarian surveyors and cartographers, to publish the achievements at home and abroad, and to maintain the necessary organizational framework.

Kulcsszavak: földmérés és térképészet ágazati irányítása, eredmények 2019-ben, feladatok 2020-ban Keywords: sectorial management of surveying and mapping, results in 2019, tasks in 2020

\section{Tisztelt Olvasók!} Kedves Kollégák!

Ismét egy mozgalmas, sok munkával töltött és sok változást hozó esztendố van mögöttünk, és most az új év elején új tervekkel tekintünk a 2020ra. Az Agrárminisztérium Földügyi és Térinformatikai Fôosztálya, a Miniszterelnökség Ingatlan-nyilvántartási és Térképészeti Fóosztálya valamint a Magyar Földmérési, Térképészeti és Távérzékelési Társaság (MFTTT) nevében köszöntjük a Geodézia és Kartográfia folyóirat minden kedves olvasóját, a Társaság tagságát, a szakterületen aktívan tevékenykedô és már nyugdíjas éveiket töltô minden kedves kollégát. Fogadják szeretettel az új évre szóló jó kívánságainkat. Sikerekben gazdag új esztendôt kívánunk továbbá a szakmai szervezeteknek, intézményeknek, gazdasági társaságoknak, amelyek a földmérés, a térképészet, a térinformatika, az ingatlan-nyilvántartás, a földügy és a távérzékelés területén végzett munkájukkal járulnak hozzá a közigazgatás múködéséhez, a szakterület fejlôdéséhez, céljainak megvalósulásához.

Visszatekintve és összefoglalva az elmúlt idôszak történéseit elmondható, hogy változásokban és tapasztalatokban bôvelkedó évben volt részünk. 2019 a szakma történetének emlékezetes dátuma marad, mivel olyan szerkezeti és szervezeti változások zajlottak le, amelyekre ötven éve nem volt példa, és hosszú távon határozzák meg a szakma jövőjét.

A kormány döntése értelmében az ingatlan-nyilvántartási és térképészeti feladatok átrendezéséról és az azzal összefüggó egyes kormányrendeletek módosításáról szóló 59/2019. (III. 25.) korm.-rendelet alapján 2019. április 1-tôl az ingatlan-nyilvántartásért, valamint a térképészetért a Miniszterelnökséget vezetô miniszter felel. Ezzel kapcsolatos feladatait az agrár- és vidékfejlesztésért, illetve földügyért felelôs miniszterrel együttmúködésben látja el. A földügyi és agrár- és vidékfejlesztési szakigazgatáshoz kapcsolódó térképészetért mint speciális területért ugyanakkor továbbra is az agrárminiszter felelôs.

További jelentôs változás, hogy 2019. április 1-tôl Budapest Fôváros Kormányhivatala Földmérési, Távérzékelési és Földhivatali Fốosztályából (a továbbiakban: BFKH FTFF) - amely 2017. január 1-tôl volt a Földmérési és Távérzékelési Intézet (FÖMI) jogutódja - az Alaphálózati és Államhatárügyi, a Földügyi Fejlesztési és Üzemeltetési, a Kozmikus Geodéziai, a Szolgáltató, a Távérzékelési, a Térinformatikai Osztály, valamint az ezen osztályoknak informatikai támogatást biztosító szervezeti egység feladatait - jogutódlással - a Lechner Tudásközpont Területi, Építészeti és Informatikai Nonprofit 
Korlátolt Felelôsségû Társaság látja el. A Lechner Tudásközpont a Miniszterelnökség szakmai háttérintézményeként múködik.

A fentiek mellett a kormány az 1150/2019. (III.25.) számú határozatában döntött a Nemzeti Földügyi Központ létrehozásáról az államigazgatási szervezetrendszer múködési hatékonyságának növelése, illetve a földügyi igazgatási feladatok egy kézben való összpontosítása érdekében. E szerint a Nemzeti Földügyi Központ (NFK) az agrárminiszter irányítása alá tartozó országos hatáskörú központi költségvetési szerv, amely 2019. július 1-jével állt fel. Ezzel együtt megszúnt a Nemzeti Földalapkezelő Szervezet, amelynek általános jogutódja az NFK.

Megszűnt továbbá a Nemzeti Kataszteri Program Nonprofit Kft. is, feladatait az NFK külön e célra létrehozott fóosztálya (Birtokrendezési Fôosztály) vette át. Ez azt jelenti, hogy 2019. július 1-tôl az NFK központi költségvetési szervként látja el a részarányföldkiadás során keletkezett osztatlan közös tulajdon megszüntetésére irányuló program (OKTM) megvalósításának koordinálását és ellenôrzését.

A BFKH FTFF földügyi, agrár- és vidékfejlesztési szakigazgatáshoz kapcsolódó, térképészeti tevékenységet ellátó szervezeti egységei szintén az NFK-ba kerültek, önálló szakmai fôosztályként (Agrár-vidékfejlesztési Térképezési Fôosztály). Az agrárvidékfejlesztési támogatással összefüggó földmérési, térképészeti, távérzékelési és térinformatikai feladatokat, ezen belül a Mezőgazdasági Parcella Azonosító Rendszer (MePAR) üzemeltetését és változásvezetését, a területalapú támogatási kérelmek ellenôrzését, a szôlổültetvények térinformatikai nyilvántartásának (VINGIS) múködtetését és a kapcsolódó helyszíni ellenôrzési feladatokat már az NFK látja el.

Az Agrárminisztériumban, 2019 februárjában a Földügyekért Felelôs Államtitkárság irányítását Zambó Péter államtitkár úr vette át. 2019. december 30-án megjelent az agrártárca új szervezeti és múködési szabályzata, amely értelmében az államtitkárság neve Erdőkért és Földügyekért
Felelős Államtitkárságra módosult. A Földügyekért Felelôs Helyettes államtitkárságot továbbra is dr. Nagy János helyettes államtitkár úr vezeti.

Az elôzô évekhez hasonlóan a 2019es év is bôvelkedett jogalkotási, jogszabály-véleményezési feladatokban, számos szakmai és funkcionális szabályváltozás történt, illetve évtizedek óta megoldásra váró kérdések rendezése is megkezdôdött.

2019-ben is folytatódott az egyes ágazati nyilvántartások tartalmának összehangolása az ingatlan-nyilvántartással, azzal a céllal, hogy létrejöjjön a konzisztens, egységes tartalom az ingatlan-nyilvántartás és az Országos Erdőállomány Adattár adatai között, valamint egyes természetvédelmi jogi jellegek bejegyzése révén a természetvédelmi szakterület nyilvántartásai és az ingatlan-nyilvántartás között.

A nyilvántartások adatainak harmonizálása kapcsán, reményeink szerint 2020-ban jelentôs elôrelépések történhetnek. A Földmérési és Térinformatikai Fóosztály - a korábbi évekhez hasonlóan - folyamatosan adott szakmai tájékoztatást az ország különbözô pontjain tartott szakmai rendezvényeken, fórumokon, amelyek közül kiemelendố az MFTTTvel közösen megrendezésre kerülô osztatlan közös tulajdon megszüntetésérôl szóló konferencia és továbbképzés, amely iránt évek óta nagy az érdeklôdés. Erre a rendezvényre az idei év során is nagy hangsúlyt kívánunk fektetni.

A 2019-es év feladatait áttekintve már prognosztizálhatók a 2020-as év bizonyos feladatai is, hiszen amint látható, számos, korábban indított feladat megvalósítása még folyamatban van.

Az elốttünk álló feladatok kapcsán a legkiemelkedőbb az osztatlan közös tulajdon megszüntetésével kapcsolatos kiemelt kormányzati célkitűzés megvalósítása, vagyis a jelenleg is futó OKTM-programnak az ütemterv szerinti folytatása. Mostanáig összesen 29462 eljárás zárult le, ami az I-V. ütemekben elindított 36534 eljáráshoz viszonyítva $81 \%$-os, a teljes projektet tekintve 55\%-os készültséget jelent. A lezárult eljárásokban mintegy 140 ezer tulajdonos részére került kiadásra az önálló tulajdonú földrészlet, hozzájárulva a tiszta tulajdoni viszonyok megteremtéséhez. 2019ben, a projekt VI. ütemében további 4500 földrészlet megosztási eljárásai kezdốdtek el. A fennmaradó 12,5 ezer földrészlettel kapcsolatos megosztási eljárások további két ütemben, 2020-2021. években indulnak, a feladatra biztosított költségvetési források függvényében.

A fentiekkel együtt az Agrárminisztérium a feladat-és hatáskörük által érintett más tárcák bevonásával vizsgálja azt, hogy az osztatlan közös földtulajdonok megszüntetése a jövóben milyen jogi eszközök, illetve eljárások kialakításával tehetô még hatékonyabbá. Az erre vonatkozó jogszabály elôkészítése jelenleg is folyamatban van.

Ahogyan már korábban említettük, 2019. április 1-jétől az ingatlan-nyilvántartásért és térképészetért a Miniszterelnökséget vezetô miniszter felel. A szervezeti átalakulás, az Ingatlan-nyilvántartási és Térképészeti Fôosztály (ITF) felállítása komoly kihívást jelentett, azonban nem állhatott le az érdemi munka sem, amely részeként a jogszabály-elôkészítésre, illetve az ingatlanügyi hatóságok szakmai irányítására irányult elsődlegesen a tevékenységünk.

A fôvárosi és megyei kormányhivatalok feletti szakmai irányítói feladat állandó feladatvégzést kíván, így ennek az eredménye is nehezen mérhetô. Ugyanakkor elmondható, hogy az ágazatot érintô munkaerôhiány miatt az ingatlanügyi hatóság oldalán keletkezó nehézségek lassan megoldódni látszanak. Emellett kiemelt tevékenység volt a Nemzeti Eszközkezelô Zrt. (NET Zrt.) által a közlejövőben benyújtandó nagy tömegú kérelmekkel kapcsolatos igazgatási feladatok, egyeztetések koordinálása is.

A jogszabály-módosítással kapcsolatos feladatok végrehajtásának egyik szelete már 2019-ben teljesült a törvénymódosításra vonatkozó elôterjesztés benyújtásával. E körben a földmérési és térképészeti tevékenységrôl szóló 2012. évi XLVI. törvény, valamint az ingatlan-nyilvántartásról szóló 1997. évi CXLI. törvény, továbbá 
- kis mértékben - az illetékekről szóló 1990. évi XCIII. törvény módosításáról, valamint a hiteles tulajdonilapmásolat igazgatási szolgáltatási díjáról szóló 1996. évi LXXXV. törvény módosult.

A 2020-ban az ITF eloott jó néhány végrehajtandó feladat áll, ezek közül a szakterületre leginkább hatással bírók a következőek lesznek:

A 2019-ról áthúzódó feladat a törvénymódosításokra épülő kormányrendelet- és miniszteri rendelet-módosításokat magába foglaló elôterjesztések elfogadtatása, kihirdetése. A módosítások hatályba lépésük esetén értelemszerúen kihatással lesznek a földmérési szakterület tevékenységére is, itt ki kell emelni az IRM-minősítéssel kapcsolatos szabályozás felülvizsgálatát, mely az IRMbizottsággal közösen történt.

Az Országgyúlés elfogadta a kormányhivatalok átalakítását, valamint az egyfokú közigazgatási rendszer kiépítésének alapjait megteremtô törvénycsomagot. Ez természetesen az ingatlanügyi és telekalakítási hatóságokra, valamint az általuk lefolytatott hatósági eljárásokra, adatszolgáltatásokra is kihatással lesz. Az ITF ezzel kapcsolatos feladata az esetlegesen szükséges, alacsonyabb szintû́ jogszabály-módosítások kidolgozása, az ezzel kapcsolatos eljárásrendek, módszertani útmutatók kidolgozása a fôvárosi és megyei kormányhivatalok részére. Ezzel kapcsolatos tennivaló a földmérési és térinformatikai államigazgatási szervvel való szoros együttmúködés annak érdekében, hogy a hatóságok munkáját támogató informatikai rendszerek szükséges módosítása is megtörténjen a 2020. március 1-jén hatályba lépó szabályozásnak megfelelően. Természetesen törekszünk arra is, hogy azokról a változásokról, melyek az ügyfeleket is érintik, mind a szakmai szervezetek, mind pedig a földmérô vállalkozók idôben értesüljenek és felkészüljenek.

A Lechner Tudásközpont Nonprofit Kft. mint földmérési és térinformatikai államigazgatási szerv a konzorciumvezetôje az e-ingatlan-nyilvántartás KÖFOP projektnek. A projekt célja elsôsorban a földügyi igazgatási eljárások elektronikus alapokra helyezése, mely így az ITF által felügyelt hatósági feladatokat nagymértékben befolyásolni fogja. Ennek megfelelően a projekt végrehajtását a fóosztály figyelemmel kíséri, egyes projekttevékenységekben aktívan közremúködik. A projekt sikeres megvalósulása esetén a kapcsolódó ingatlan-nyilvántartási, telekalakítási és egyéb eljárások az ügyfelek számára is nagymértékben egyszerúbbek, gördülékenyebbek lesznek.

A fóosztály továbbra is szeretné fenntartani a kapcsolatot a szakmai szervezetekkel, amelynek kiépítése 2019-ben sikeresen elkezdôdött. Ez nemcsak a szervezetek által rendezett konferenciákon, szakmai napokon való részvételt jelenti. Egy jogszabály a megalkotása során, a kezdeti vázlatoktól a hatályba lépésig, rendkívül hoszszú utat jár be, számtalan véleményezésen megy keresztül. Ennél fogva az alapjavaslatok, ötletek, igények véglegesítése és minden érintett általi elfogadása sok egyeztetést és kompromiszszumkötést kíván. A hosszadalmasnak és bonyolultnak tûnô közigazgatási procedúra nem jelentheti azt, hogy a szakmagyakorlók igényeit (idô hiányában) már nem kellene, nem lehetne figyelembe venni vagy támogatni. Erre tekintettel a szakmai együttmúködés ki fog terjedni a fóosztály jogszabály-elôkészítô feladataiban történố közremúködésre is.

Látható tehát, hogy a 2020-as év sem telik majd eseménytelenül, a már most elốre tervezhetô rövid és középtávú feladatok sikeres végrehajtása is kiemelt aktivitást követel meg a fôosztály részérôl. Noha részleteiben nem említettük, de természetesen folyamatos munkát igényel a Földrajzinév-bizottsággal kapcsolatos koordináció, az IRM-bizottság elnökének tevékenységével járó feladatok, az államhatárral kapcsolatos nemzetközi kötelezettségek ellátása, az új felmérések elindításával kapcsolatos egyeztetések lefolytatása és számos, az ITF mindennapi életében jelen levó feladat, amelyeket ugyan külön nem emeltünk ki, de jelentőségük nem elhanyagolható.

Az MFTTT életében a 2019. esztendő egészében véve eredményes és sikeres volt. A szakmai elốadásainkon és rendezvényeinken a tagság részérôl viszonylag nagy számban vettek részt. A nehézségek ellenére a Társaság pénzügyi egyensúlyát intézőbizottságunk (IB) döntései alapján meg tudtuk teremteni, és a múködőképességét folyamatosan biztosítottuk. Az ehhez szükséges anyagi forrást egyrészt a Budapesti és Pest Megyei Mérnöki Kamarával (BPMK) korábban kötött együttmúködési megállapodásunk keretében a Geodézia és Kartográfia (GK) szakmai folyóiratunk nyomdai költségeinek részbeni fedezetére kapott mintegy 600000 Ft-os támogatás, másrészt az év folyamán befolyt egyéni és jogi tagdíjak, a GK előfizetési díjai, a GK-ban megjelent hirdetések díjai, továbbá a rendezvényeink eredményei, valamint az NKP (Nemzeti Kataszteri Program) Nonprofit Kft.-tôl most már harmadik alkalommal kapott, kiemelt összegú (több mint két millió Ft) támogatás tették lehetôvé. A GK kiadásának elôsegítésére a Nemzeti Kulturális Alaptól (NKA) pályázattal elnyert támogatás $(500000 \mathrm{Ft})$ is sokat segített.

Jól ismert, hogy Társaságunk egyedüliként képviseli hazánkat három szakmai világszervezetben, nevezetesen a Földmérôk Nemzetközi Szövetségében (FIG), a Nemzetközi Térképészeti Szövetségben (ICA) és a Nemzetközi Fotogrammetriai és Távérzékelési Társaságban (ISPRS). Ezen felül másik két hazai szervezettel, a Magyar Földmérô és Geoinformatikai Vállalkozások Egyesületével (MFGVE) és a Magyar Mérnöki Kamarával (MMK), illetve az MMK Geodéziai és Geoinformatikai Tagozatával (MMK-GGT) együtt komoly a szerepvállalásunk az Európai Földmérôk Tanácsában (CLGE) is. Annak ellenére, hogy kérésünkre a két szakmai fơhatóságunktól 2019-ben nem kaptunk támogatást (sem az Agrárminisztériumtól, sem a Miniszterelnökségtôl) be tudtuk fizetni a nemzetközi szakmai szervezeteknek a 2019. évi tagdíjunkat (amely a négy nemzetközi szervezet esetében összesen 1306084 Ft-ot tett ki). Társaságunk képviseltette magát az ICA rendezvényein, köszönhetôen annak, hogy 2011-2019 között 
a szervezet főtitkára, jelenleg pedig az alelnöke dr. Zentai László egyetemi tanár, az ELTE Térképtudományi és Geoinformatikai Tanszékének vezetôje. A Tanszék munkatársai nagy számban vettek részt az ICA tokiói kongresszusán. Társaságunkat Vidovenyecz Zsolt kollégánk képviselte a CLGE tavaszi általános közgyưlésén (Szófia, Bulgária, 2019. március 21-23.) és az ôszi közgyưlésén is (Isztambul, Törökország, 2019. szeptember 26-28). Iván Gyula, a FIG Magyar Nemzeti Bizottság (MNB) titkára és Varga Felícián tagtársunk vett részt Társaságunk nevében a FIGmunkahét (Working Week) elnevezésû́ rendezvényen és a FIG 42. közgyưlésén (Hanoi, Vietnam, 2019. április 22-25.) is.

Társaságunk nemzetközi tevékenységéhez szorosan kapcsolódik az IB által korábban létrehozott MFTTTWG4SDG-munkabizottság (elnöke: dr. Mihály Szabolcs, tagjai: Hargitai Péter, Iván Gyula, dr. Remetey-Fülöpp Gábor, Palya Tamás és dr. Zentai László) múködése. Aktívan képviselik Társaságunkat elôadásokkal és tanulmányok készítésével az ENSZ Fenntartható fejlődési céljai elérésének szolgálatában megjelenố térinformatikai és földmegfigyelési feladatok terén. Munkájuk eredményeként megjelent publikációk és elôadási anyagok rövidesen olvashatók lesznek az MFTTT honlapján elkülönített menüpontban.

Társaságunk - az alapszabályával összhangban - folytatta eredményes együttmúködését az Erdélyi Magyar Mûszaki Tudományos Társaság (EMT) Földmérố Szakosztályával (FSz). Az EMT FSzáltal szervezett jubileumi, XX. Földmérôtalálkozón (Marosvásárhely, 2019. május 23-26.) szép számban vettünk részt Magyarországról, és számos szakmai előadást is tartottunk. A találkozón 76 anyaországi és 36 erdélyi kolléga regisztráltatta magát. A jubileumi, XX. találkozó alkalmából Társaságunk fotóalbum készítését határozta el, amelyet Hodobay-Böröcz András tagtárs tervezett meg, állított össze, és a nyomtatás megszervezését is ô végezte. A két szervezet együttmúködése keretében, a székely származású Márton Gyárfás professzor emlékére alapított közös szakmai emlékplakettet már hetedik alkalommal ítéltük oda. A 2019. évi kitüntetést Budaházi Endre László részére az EMT Földmérô Szakosztályának elnöke, dr. Ferencz József adta át Nagyváradon, dr. Csemniczky Lászlónak pedig a Társaságunk 32. Vándorgyúlése keretében (Békéscsabán, 2019. július 4-én) adtuk át. Az elôzô hat alkalommal a következó tagtársak kapták meg a Márton Gyárfás-emlékplakettet (először az erdélyi, majd az anyaországi tagtárs nevét adjuk meg): 2013-ban dr. Ferencz József és Hodobay-Böröcz András, 2014-ben Máté Sándor és dr. Siki Zoltán, 2015-ben dr. Suba István és dr. Joó István (posztumusz), 2016ban Márton Huba és Homolya András, 2017-ben Zágorszki Tibor és Varga Gábor és 2018-ban Imre László és Bartos Ferenc.

Szakosztályaink és területi csoportjaink többsége a lehetőségekhez mérten aktívan és eredményesen múködött. Külön is kiemeljük a Felmérési és Területrendezési Szakosztályt, a Fotogrammetriai és Távérzékelési Szakosztályt, a Geodéziai Szakosztályt, a Kartográfiai Szakosztályt, a Mérnökgeodéziai Szakosztályt, a Szakmatörténeti Szakosztályt, a Topográfiai Szakosztályt és a Szeniorok Tóth Ágoston Klubját a rendszeres találkozóik okán. Sikeresek és eredményesek voltak a területi csoportjaink által az év folyamán szervezett rendezvények is. Így például (idôrendi sorrendben):

- Földmérônap Miskolcon

(2019. február 26.),

- Fôvárosi és Pest Megyei Földmérônap (Budapest, 2019. április 3.),

- XI. Tavaszi Mérnöknap,

Nógrád-2019

(Salgótarján, 2019. április 9.),

- Tolna Megyei Földmérônap és Továbbképzés (Szekszárd, 2019. május 24.),

- Zalai Geodéták Találkozója (Zalaszabar, 2019. szeptember 24.),

- Földméró Szakmai Nap (Pécs, 2019. november 7.),

- Földmérô Szakmai Nap (Nyíregyháza, 2019. december 3.). A Békés Megyei Földmérō Szakmai Napokat 2019. november 21-22-ére tervezték Békéscsabára, de csak 2020 februárjában fogják megrendezni. Ezeket az összejöveteleket többnyire a megyei mérnöki kamarákkal (illetve annak a Geodéziai és Geoinformatikai Tagozatával) és a Kormányhivatalok földhivatali fóosztályaival együttesen szervezték meg, amelyekre minden alkalommal legalább 100-130 fó regisztrált, de a Fôvárosi és a Pest Megyei területi csoport által szervezett, valamint a Békés megyei rendezvény résztvevôinek létszáma már sokadik alkalommal érte el, sốt haladta meg a 200 fôt. Ezen felül területi csoportjaink több megyeszékhelyen múködtek közre a mérnöki kamara szervezésében rendezett továbbképzô elôadások szakmai programjának összeállításában.

Hetényi Ferencné szervezésében kiemelkedôen sikeres volt a Szeniorok Tóth Ágoston Klubja által a csehországi kastélyok megtekintésére szervezett kétnapos kirándulás 2019 szeptemberében. Figyelemre méltó továbbá, hogy Társaságunk Vas Megyei Területi Csoportja Bolla Attila és Nagy István tagtársak szervezésében a Nemzeti Összetartozás Napján (2019. június 4-én) barátiszakmai összejövetelt rendeztek Szombathelyen.

Társaságunk folyamatos múködtetése céljából az elmúlt év során 6 IBés 3 választmányi ülést tartottunk, továbbá két alkalommal hívtuk össze a közgyúlést. A testületi üléseinken hozott fontosabb döntéseinket határozatokba foglaltuk. 2019-ben összesen 20 IB-határozatot, 5 választmányi és 9 közgyűlési határozatot hoztunk, amelyek a Társaságunk honlapján elérhetôk, illetve a Titkárságon tanulmányozhatók. A Társaság 2019. évi Lázár deák emlékérmét választmányunk Zalaba Piroska tagtársunknak ítélte oda, melyet a Békéscsabán szervezett 32. Vándorgyưlés plenáris ülése keretében adtunk át.

Az alapszabályunkat nem módosítottuk, bár a teljes körú tartalmi összhang elérése (az apróbb ellentmondások megszüntetése) és a szakosztályok szakmai szempontú átalakítása kisebb változtatást tesz indokolttá a közeli jövőben. 
Testületi üléseinkre a felügyelôbizottság elnökét és tagjait mindig meghívtuk, akik rendszerint részt is vettek azokon, és konstruktív észrevételeikkel nagyban segítették a Társaság múködtetését.

Társaságunk részérôl ismételten jól koordinált munkát jelentett - a szúkre szabott határidô miatt is - az új földmérési és térképészeti törvényhez kapcsolódó végrehajtási rendeletek véleményezése. Ezen túl az IB Zsilvölgyi Csaba vezetésével eseti bizottságot kért fel a szakmai problémák összegyújtésére, megoldási javaslatokra és ezek szövegszerú jogszabály-módosítási megfogalmazására, melyet az illetékes szakmai fóhatóság (Miniszterelnökség ITF) részére megküldtünk.

Képviseltettük a Társaságunkat többek között a száz éves magyar katonai térképészet napján (február 1-én) rendezett ünnepi állománygyúlésen, a 2019. évi Eötvös Loránd-emlékévet szervezô bizottság ülésein stb.

Az Európai Földmérốk Tanácsa (CLGE) a földmérômérnöki foglalkozás és a földmérôk által végzett fontos tevékenység megbecsülése és a köznyilvánosság elôtti elismertetése céljából 2019-ben március 21-ét (immár nyolcadik alkalommal) az „Európai Földmérôk és Geoinformatikusok Napjává" nyilvánította. Ehhez a rendezvénysorozathoz egész napos konferenciával (EFGN 2019) kapcsolódtunk március 21-én, amelynek szakmai programját az MFTTT szervezte a magyarországi földméróket és térképészeket képviselő másik két szervezettel (MFGVEés az MMK-GGT) együttmúködésben. A konferencia védnöke dr. Nagy István agrárminiszter volt. Az elôadókat szakterületünk meghatározó állami, katonai, vállalati és oktatási intézményeiból választottuk. A rendezvényen valamivel több, mint 200-an vettek részt. Ehhez a konferenciához kapcsolódott az április 3-án szervezett „Fơvárosi és Pest Megyei Földmérônap” elnevezésû előadóülés. Az említett két rendezvényt az eredményes pályázatunknak köszönhetôen az Emberi Erôforrás Támogatáskezelố Nemzeti Kulturális Alapja (NKA) is támogatta 500000 forinttal. Megjegyezzük, hogy március 21-ét a FIG kezdeményezése és döntése alapján a Földmérôk Világnapjává (Global Surveyors Day) is nyilvánították, amelyet most második alkalommal világszerte megünnepeltek. A Földmérôk Világnapját mi az EFGN 2019 rendezvénnyel együtt szerveztük meg.

Az ôszi nagyrendezvényünket az Agrárminisztérium (AM) Földügyi és Térinformatikai Fôosztályával és az AM Nemzeti Földügyi Központja (NFK) Birtokpolitikai Fôosztályával együttesen az „Osztatlan közös tulajdon megszüntetésének szabályairól szóló 374/2014.(XII. 31.) kormányrendelet végrehajtásához kapcsolódó továbbképzés és fórum" címmel 2019. november 12-én a Magyar Honvédség Geoinformációs Szolgálata (MH GEOSZ) kultúrtermében szerveztük meg. Felkérésünkre dr. Nagy István agrárminiszter úr vállalta a konferencia fôvédnökségét. A nagy érdeklődés mellett lezajlott rendezvényen mintegy 250 fô (többségében földhivatali munkatárs) vett részt.

Folytattuk Társaságunk (elsôsorban az említett szakosztályaink szervezésében) tavaszi és az ôszi-téli szakmai előadássorozatának lebonyolítását továbbképzési jelleggel. Az elôadások egy részét a korábbi FÖMI tanácstermében, a nagyobbik részét pedig kihelyezett helyszíneken (BME Általános- és Felsôgeodézia Tanszékén, a Fotogrammetria és Térinformatikai Tanszékén, az ELTE Térképtudományi és Geoinformatikai Tanszékén és az Óbudai Egyetem ARMK Geoinformatikai Intézetében) tartottuk meg. Ez azért is szerencsés helyzet, mert az egyes előadásokon így egyetemi hallgatók is részt vesznek.

Köszönjük, hogy 2019-ben is Társaságunk tagjai maradtak, fizették a tagdíjat, és ezzel is segítették munkánkat. Társaságunk közgyúlésének 2019. december 10-ei döntése alapján a 2020. évi tagdíjak az elôzó évhez képest nem változtak. Ennek értelmében az aktív dolgozók esetében a tagdíj $10000 \mathrm{Ft}$, diákok, egyetemi hallgatók és nyugdíjasok számára változatlanul $5000 \mathrm{Ft}$ (lapelőfizetés nélkül $1000 \mathrm{Ft}$ ). A GK szakmai folyóiratunk elófizetési díja a nem MFTTT-tagok és közületek részére továbbra is $18000 \mathrm{Ft}+$ áfa. A jogi tagdíjak összege sem változott. Az egyéni tagjainknak teljes körú hozzáférést biztosítunk a honlapunkhoz (www.mfttt.hu), és természetesen a tagdíj befizetése ellenében rendszeresen kapják a szakmai folyóiratunkat. Emellett Társaságunk tagjai az MFTTT rendezvényein alacsonyabb részvételi díjjal vehetnek részt.

Köszönettel tartozunk azoknak is, akik anyagilag is támogatták Társaságunkat. Igen sok magánszemély tisztelt meg minket bizalmával és szerény adománnyal. Az intézmények, cégek közül pedig kiemelt köszönet illeti az NKP Nonprofit Kft.-t a segítségéért, de nem működhetne titkárságunk a Budapest Fôváros Kormányhivatala, illetve a Lechner Tudásközpont által biztosított infrastruktúra nélkül sem. Rendezvényeinkhez folyamatosan kiemelt segítséget kaptunk az MH Geoinformációs Szolgálattól, hiszen a 200-300 fôt is meghaladó tavaszi és ôszi rendezvényeink számára immár ötödik éve biztosítottak helyszínt a Szilágyi Erzsébet fasori székhelyükön.

Társaságunk múködése szempontjából fontos együttmúködési megállapodást kötöttünk a Magyar Honvédség Geoinformációs Szolgálatával és az Osztrák Földmérési és Geoinformatikai Egyesülettel (Österreichische Gesellschaft für Vermessung und Geoinformation).

A 2020. év is mozgalmasnak ígérkezik az MFTTT életében. Néhány kiemelt feladatunk: a Társaság pénzügyi egyensúlyának megốrzése, melyet alapvetôen a taglétszám megtartásával, továbbá eredményes pályázati tevékenységgel, valamint a társszervezetekkel és szakmai intézményekkel, szakmai fóhatóságainkkal meglévố kapcsolatok erôsítésével remélünk biztosítani. Fontosnak tartjuk az MFTTT taglétszámának emelését is. Jelenleg 516 fó egyéni regisztrált és 33 jogi tagunk van. Az egyéni taglétszámmal nem lehetünk elégedettek, annál is inkább, mert tudomásunk szerint az MMK-GGT keretében valamivel több, mint 1100 regisztrált földmérố kamarai tagot tartanak nyilván. Sajnos a fiatal szaktársainkat 
nehéz megnyerni a társasági (közéletitársadalmi) munkára. A fiatal kollégák megnyerése céljából diplomadíjakat adunk át végzốs, kiváló diplomamunkát készítô egyetemi hallgatók számára. A jutalmazás részét képezi az elismerố oklevél mellett az egy évre szóló MFTTT-tagság és természetesen a vele járó GK szakmai folyóiratunk is a teljes évre. 2019-ben a BME öt hallgatója (Bogár Ádám, Horváth Viktor Gyốzố, Hrutka Bence Péter, Nagy Nándor Antal és Papp Viktor) részesült ilyen diplomadíjban.

Szeretnénk elérni, hogy a nemzetközi szervezeteknek a 2020. évi tagdíjunkat is be tudjuk fizetni. (Ebbốl a célból az elmúlt év végén levélben azzal a kéréssel fordultunk a szakmai fốhatóságunk egyik vezetôjéhez, dr. Bíró Attila helyettes államtitkárhoz, hogy a Miniszterelnökség nyújtson anyagi támogatást az MFTTT részére.) Fontos célkitûzésünk az Európai Földmérốk és Geoinformatikusok Napja és a Földmérốk Világnapja (EFGN 2020, 2020. március 19.), valamint az ôszi szakmai nagyrendezvényünk eredményes és sikeres megszervezése és lebonyolítása (a tavalyi témakörben: „Részarány-földkiadás során keletkezett osztatlan közös tulajdon megszüntetése projekt tapasztalatai”), továbbá az EMT FSz XXI. Földmérốtalálkozón (Székelyudvarhely, 2020. május 21-24.) a sikeres szereplés. Az Európai Földmérố és Geoinformatikusok Napja és a Földmérôkk Világnapja rendezvényének eredményes és sikeres lebonyolításához (pályázat útján) 300000 Ft NKA-támogatásban is részesülünk.

Itt jegyezzük meg, hogy 2012 óta az egyes országok elốterjesztésére a CLGE általános közgyưlésének jóváhagyása alapján - az EFGN elốadóülések keretében, a szakmánk szempontjából kiemelkedố személyekrổl, a múltban végzett földmérési/geodéziai/matematikai munkálatról is megemlékezünk. Így 2012-ben - születésének 500. évfordulója alkalmából - Gerardus Mercator (1512-1594) holland kartográfusról, 2013-ban Galileo Galilei (1564-1642) olasz csillagász-fizikusról, 2014-ben Friedrich Georg Wilhelm von Struve (17931864) orosz csillagászról és a róla elnevezett, az UNESCO által 2005ben a világörökség részévé nyilvánított Struve-féle meridiánív geodéziai jelentôségérốl és hasznosításáról, 2015-ben Eukleidész (Kr. e. 366 ? -Kr. e. 300?) görög matematikusról és a róla elnevezett euklideszi geometria alkalmazásáról, 2016ban Roger Joseph Boscovich/ Ruđer Josip Bošković (1711-1787) horvát tudósról, 2017-ben Guillaume-Henri Dufour (1787-1875) személyérổ, a svájci állami földmérés szervezetének megalapítójáról és elsố vezetôjérốl (1838-1865), 2018-ban Carl von Ghega (1802-1860) osztrák mérnökrốl (építốmérnökrốl), a semmeringi vasút (amelyet az UNESCO 1998ban a kulturális világörökségi helyszínek közé vett fel) tervezôjérôl és építésirányítójáról emlékeztünk meg. Számunkra elismerésre és figyelemre méltó, hogy 2019-ben halálának 100. évfordulója alkalmából Eötvös Loránd (1848-1919) tevékenysége került a középpontba Magyarország elốterjesztése alapján. (A döntés a CLGE 2018. évi tavaszi általános közgyưlésén született meg). Így az elmúlt évben Eötvös Loránd volt az ünnepelt európai földmérố (,The European Surveyor of the Year 2019"), akinek személyérốl és tudományos tevékenységének hatásáról európai szinten (központilag a CLGE tavaszi általános közgyûlésén) és az egyes országok szintjén is megemlékeztünk. A fentiek miatt különösen fontos rendezvényünk volt az EFGN 2019 elốadóülés és hazánk képviselete a CLGE tavaszi általános közgyúlésén (Szófia, Bulgária, 2019. március 20-22-én). Törökország elốterjesztésére és a CLGE legutóbbi általános közgyứlésének döntése alapján idén Piri reisz (teljes nevén Hadzsi Ahmed Muhiddin Piri, 1470-1553) lesz az ünnepelt európai földmérố. (reisz=oszmán török tengernagy)

2020-ban egyik kiemelkedố fontosságú feladatunk lesz az MFTTT soron következố, 33. Vándorgyûlésének eredményes megszervezése és sikeres lebonyolítása. Helyszínérôl és idốpontjáról már 2019-ben, az IB egyik ôszi ülésén döntöttünk (Miskolc, 2020. július 9-11). A helyi szervezôbizottság elnöki feladatainak ellátására
Plesovszki Adrienn tagtársat kértük fel.

Továbbra is szükségesnek tartjuk a GK szakmai folyóiratunk kiadását és színvonalas megjelentetésének biztosítását, az egyre népszerûbbé váló honlapunk folyamatos mûködtetését és feltöltését a Társaságunkra vonatkozó idốszerû́ ismeretekkel (pl. kitüntetettjeink, örökös és tiszteleti tagjaink teljes jegyzéke stb.). Fontos fejlemény, hogy a Geodézia és Kartográfia (GK) 2017 novemberétổ újra indexálásra került a Scopus adatbázisban, továbbá bekerült az ELTE Digitális Tudástárába (EDIT) is. 2019ben pedig elkészült a GK eddig megjelent valamennyi lapszámának a digitális változata, és megtörtént a digitális publikálása az Arcanum Adatbázis Kft.-vel együttmûködésben. Erre vonatkozóan a kiadói jogokat gyakorló MFTTT és az Arcanum Adatbázis Kft. szerzốdést írt alá, melyet Buga László, a GK fốszerkesztổje készített elô, és ố szervezte meg a kapcsolódó munkákat is.

Biztosítjuk a testületi ülések (a körülmények alakulásától függốen hat-nyolc IB- és három-négy választmányi ülés, valamint két-három közgyưlés) lebonyolítását. Az elsổ közgyûlést 2020. május végén fogjuk tartani.

Társaságunk 2020-ban is nagy hangsúlyt fektet olyan akkreditált, továbbképzés-jellegû́ konferenciák szervezésére, melyekkel lehetôséget teremtünk tagjaink számára, hogy megszerezzék a szakmájuk gyakorlásához elốírt kreditpontokat.

Képviseltük Társaságunkat a Földtudományi Civil Szervezetek Közösségének (FöCiK) rendezvényein. A 2014. június 24-én aláírt együttmûköodési megállapodás értelmében a FöCiK jelenleg tíz (korábban a MTESZ keretei között mû́ködố) földtudományi szakmai civil szervezetet foglal magában. Társaságunk (immár ötödik alkalommal) önálló kiállítással jelent meg a FöCiK szervezésében megvalósuló „Földtudományos Forgatag" rendezvényén is 2019. november 9-10-én, és ezt tervezzük 2020ban is november 7-8-án. A FöCiK legutóbbi ülésén (2019. december 12-én) választották meg a szervezet hatodik 
elnökét, dr. Zelei Gábor (a Magyar Geofizikusok Egyesületének elnöke) személyében. A FöCiK elnöki tisztsége egy év időtartamra szól, és forgószínpad-szerúen a szervezetet alkotó földtudományi szervezetek elnökei közül választjuk. A korábbi elnökök: Baksa Csaba (2014/2015), dr. Gábris Gyula (2015/2016), dr. Dunkel Zoltán (2016/2017), dr. Szlávik János (2017/2018) és dr. Leél-Ôssy Szabolcs (2018/2019) voltak.

Társaságunk részéről 2020-ban is megbeszélést fogunk kezdeményezni az együttmúködési lehetôségekrôl a szakágazat fôhatósági vezetốivel, lehetôség szerint államtitkári

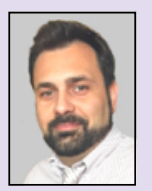

\section{Dr. Nagy Levente} fóosztályvezetô

Agrárminisztérium Földügyi és Térinformatikai Fóosztály szinten. Erre valószínúleg már tavaszszal sor kerülhet, ha lezárulnak a szakmánk polgári (civil) területén a hosszú ideje húzódó szervezeti átalakulások. A 2019. év egészében véve úgy telt el, hogy érdemben alig tudtunk felsőbb szintû́ vezetôkkel találkozni, megbeszélést folytatni. Lényegében csak két rövid találkozót tudunk említeni: dr. Tóth Balázs fốosztályvezetô (a Miniszterelnökség Hatósági Ügyekért Felelôs Helyettesállamtitkárság, Ingatlan-nyilvántartási és Térképészeti Fôosztály vezetôje) augusztus 28-án fogadta rövid bemutatkozó látogatáson az MFTTT vezetőit, és Nagy János elnök (az AM

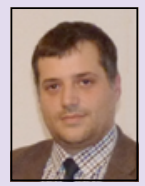

Dr. Tóth Balázs föosztályvezetô

Miniszterelnökség Ingatlan-nyilvántartási és Térképészeti Fóosztály
Nemzeti Földügyi Központ vezetôje) szeptember 18-án találkozott az MFTTT vezetôivel. Reméljük, hogy 2020-ban a szervezeti átalakulás lezárása után teljes egészében a szakmai munkára lehet az erôket koncentrálni.

Az idei év jelentôs feladatainak megvalósításában számítunk a szakma képviselôiinek támogató együttmúködésére, szakértelmükkel hozzájárulva a közös célok eléréséhez.

Ezen munkához minden kedves partnerünknek, csakúgy, mint olvasóinknak jó egészséget, sok sikert kívánunk!

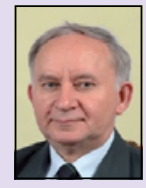

Dr. Ádám József elnök

Magyar Földmérési, Térképészeti és Távérzékelési Társaság 